\title{
The 1853 Mormon Migration through Keokuk
}

\author{
FRED E. WOODS \\ AND DOUGLAS ATTERBERG
}

IN MAY 1853 William W. Belknap, who would later serve as a major general in the Civil War and as Secretary of War to President Grant, wrote to his sister, Clara, about the Mormon emigrants who were outfitting in Keokuk, Iowa, that spring and summer.

Yesterday was Sunday \& I wish you had been here to go up to the Mormon Camp with me. They had preaching at three stands in three languages-English, German \& Danish. They singespecially the Danes-very sincerely \& are perfectly enthusiastic. It is a strange, strange mystery \& if you were here you'd be astonished. There are nearly 3500 here now and "still they come" by every boat \& some of them are genteel and many of the girls very pretty. ... The Mormons are mainly honest, earnest \& sincere.'

Keokuk residents such as Belknap may have considered the Mormon emigrants who made Keokuk their outfitting post in 1853 as curiosities, but the young town garnered lasting benefits from the emigrants' temporary presence. The Mormons, for their part, found that Keokuk offered an adequate temporary solution to their search for an outfitting point for the faithful Saints, especially those from abroad, who were being called to gather in the Salt Lake Valley.

1. William W. Belknap to Clara Belknap, 9 May 1853, William W. Belknap Correspondence, microfilm, Keokuk Public Library. The Keokuk Public Library gave the original correspondence to Princeton University.

THE ANNALS OF IOWA 61 (Winter 2002). (C) The State Historical Society of Iowa, 2002. 
LESS THAN SIX MONTHS after the founding of The Church of Jesus Christ of Latter-day Saints, the Mormon Prophet Joseph Smith received the call to gather all of the Saints: "And ye are called to bring to pass the gathering of mine elect; ... [ [and] they shall be gathered unto one place upon the face of this land. ${ }^{\prime \prime 2}$ The Latter-day Saints in America first gathered in New York (1830-31); then, because of persecution, they migrated to Ohio and Missouri (1831-38). In the late fall of 1838 and winter of 1839 , they crossed the Mississippi and eventually found another gathering place in Nauvoo, Illinois, by the spring of 1839 .

The tide of Mormon immigration to America from overseas would not commence until 1840, when Latter-day Saint missionaries obtained a firm foothold in the British Isles. ${ }^{3}$ From 1840 to 1846, the Mormon immigrants gathered in Nauvoo before local mobs forced them to leave the city. In July 1847, a vanguard company led by Brigham Young entered the Salt Lake Valley and established the nucleus of a new gathering place in the West. That arid desert area "blossomed as a rose" and became a Mormon mecca for converts who gathered from throughout the world.

From 1849 to 1852 , the area of Kanesville, Iowa, became the designated outfitting post to send Mormon emigrants across the

2. The Doctrine and Covenants of The Church of Jesus Christ of Latter-day Saints, 29:7-8. The Church of Jesus Christ of Latter-day Saints was founded on April 6, 1830, in Fayette, New York.

3. The gathering of the Saints did not commence until 1836. The following year, Joseph Smith called Elder Heber C. Kimball to lead a mission to England. He and fellow Apostle Orson Hyde led a small group of missionaries who found great success in the British Isles. Smith had warned them "to remain silent concerning the gathering .... until such time as the work was firmly established, and it should be clearly manifest by the spirit to do otherwise." See Joseph Smith Jr., History of The Church of Jesus Christ of Latter-day Saints, ed. B. H. Roberts, $2 d$ ed., rev., 7 vols. (Salt Lake City, 1971), 2:242. Their groundbreaking work would be greatly augmented by the mission of the Twelve Apostles in 1840-41. For excellent accounts of these early missions, see James B. Allen, Ronald K. Esplin, and David J. Whittaker, Men with a Mission, 1837-1841: The Quorum of the Twelve in the British Isles (Salt Lake City, 1992); James B. Allen and Malcom R. Thorp, "The Mission of the Twelve to England, 1840-1841: Mormon Apostles and the Working Classes," Brigham Young University Studies 15 (1975), 499-526.

4. On the Mormon migration to Nauvoo, see Fred E. Woods, "Gathering to Nauvoo: Mormon Immigration, 1840-1846," Nauvoo Journal 11 (Fall 1999), 43-64. 
plains to the Salt Lake Valley. It also served as a temporary gathering place for those Latter-day Saint emigrants who did not have the resources to make it all the way to the Salt Lake Valley.

During that same period, the California gold rush brought thousands of westward-bound emigrants through Salt Lake City, creating a financial windfall for the Saints that made it possible to send Mormon missionaries to Europe. Those missionaries were especially successful in securing converts in the British Isles and Scandinavia. Resources also became available to create a revolving fund in 1849 known as the Perpetual Emigrating Fund. In 1852 that fund, which had first been used to aid Nauvoo exiles, became available to help poor foreign converts emigrate to the Salt Lake Valley.

In the meantime, some Saints had found employment in river cities such as New Orleans, St. Louis, and Kanesville and were content to stay where they were. In 1852 Brigham Young instructed all church members to do their utmost to gather with the Saints in the Salt Lake Valley. ${ }^{6}$ Most Latter-day Saints in the Kanesville area heeded the call and migrated to Utah. When the remaining non-Mormon merchants in the city (renamed Council Bluffs) inflated the prices for passing emigrants, church officials decided to find a new frontier outfitting post for the following migration season.?

5. Leonard J. Arrington, Great Basin Kingdom: An Economic History of the Latterday Saints, 1830-1890 (Lincoln, NE, 1958), 77-78. On the forty-niners passing through Kanesville, see Fred E. Woods, "More Precious than Gold: The Journey to and through Zion in 1849-1850," Nauvoo Journal 11 (1999), 116-17.

6. "Seventh General Epistle of the Presidency of The Church of Jesus Christ of Latter-day Saints," The Latter-day Saints Millennial Star 14 (17 July 1852), 325. Historian Andrew Jenson, "Church Emigration XV: Detailed Emigration Account, 1853," The Contributor 13 (August 1892), 466, says that church officials decided that once Kanesville shut down as the outfitting post in 1852, foreign converts who could not afford to migrate all the way to Utah should no longer be sent to America. Prior to that time, immigrants had been advised to get to the States and then as far west as they could, stopping if need be in towns such as Kanesville until they could afford to continue the journey. Commencing with the 1853 emigration season, European converts were to move through in a continuous journey to Utah.

7. William G. Hartley, "Mormons and Early Iowa History (1838 to 1858): Eight Distinct Connections," Annals of Iowa 59 (2000), 249; Alois J. Weber, "History of Mormon Encampment in 1853," Lee County Historical Society Publication No. 7 (Keokuk, 1963), 4. 
The migration route for European converts had been established for over a decade. Since 1840, chartered companies of foreign converts embarked from Liverpool for New Orleans. They migrated to Nauvoo until 1846. After the Saints found a new gathering place in the Salt Lake Valley in 1847, the immigrants left the Mississippi at St. Louis and continued their maritime route on the Missouri until arriving at the Council Bluffs/ Kanesville area, where they outfitted for the journey across the plains. In 1853, however, immigrants would not disembark at St. Louis. Instead, they would continue up the Mississippi to Keokuk, which was designated as that year's outfitting post. ${ }^{8}$

Church officials wanted to avoid not only the inflated outfitting costs at Council Bluffs, but also the treacherous Missouri River itself. The previous year, Latter-day Saints had experienced the worst maritime disaster in the history of Mormon migration when the boiler on the steamboat Saluda exploded, killing more than two dozen Mormon converts." British artist Frederick Piercy, who sketched segments of the Latter-day Saint journey from Liverpool to Salt Lake, noted, "At St. Louis I learned that the Emigrants to G.S.L. Valley, instead of going up the dangerous Missouri in steam-boats would, this year (1853), start from Keokuk and cross the State of Iowa to Kanesville."10 The Saints would thus avoid river travel on the Missouri, but in

8. According to the 1997-98 Church Almanac (Salt Lake City, 1996), 1159-61, more than 18,000 Mormon immigrants passed through New Orleans from 1841 through 1855. In 1855, the incoming Mormon immigrants were no longer sent through New Orleans due to the threat of diseases, such as yellow fever and especially cholera, associated with the Mississippi River. In 1854 church president Brigham Young cited these risks and encouraged immigrants to use the eastern ports of Philadelphia, Boston, or New York. Brigham Young to Franklin D. Richards, 2 August 1854, "Foreign Correspondence," Millennial Star 16 (28 October 1854), 684.

9. Conway W. Sonne, Saints on the High Seas: A Maritime History of Mormon Migration (Salt Lake City, 1983), 103-4, estimates that as many as 90 of the 175 passengers were Mormons. This steamboat disaster is considered the worst in the history of navigation on the Missouri River. William G. Hartley and Fred E. Woods have written a book, Explosion of the Steamboat Saluda, released at the sesquicentennial commemoration of this tragic event in Lexington, Missouri, April 9, 2002.

10. Frederick Piercy, Route from Liverpool to Great Salt Lake Valley, Illustrated, ed. James Linforth (Liverpool and London, 1855), 58. 
exchange they would have an extra 300 miles of overland travel with teams across Iowa."

THE LATTER-DAY SAINTS' first connection with Lee County (home to Keokuk) came when they fled Missouri in late 1838 and during the winter of 1839. Most of the exiles took refuge in Quincy, Illinois, then the largest town north of St. Louis, but a few dozen led by Israel Barlow got lost on their way to Quincy and wandered northeast to the Des Moines River. Near an area now known as Montrose, Iowa, they moved into an abandoned army post called Fort Des Moines. There they met Isaac Galland, a land speculator of dubious reputation, who in 1837 had platted the "City of Keokuk."

Keokuk was then only a sleepy village of perhaps 150 people, its future being retarded by a political curiosity called the Half Breed Tract. Isaac Galland had promoted settlement of this 119,000 -acre area in the southeastern tip of Iowa. He made little progress, however, until the Mormon refugees introduced him to Joseph Smith. When Galland offered the Mormon prophet a valid title to the Commerce town site that became Nauvoo, Illinois, he also offered him dubious title to several square miles of farmable land in the Half Breed Tract for which he held "quit claim" deeds. $^{13}$

Joseph Smith saw the advantage of Iowa farmlands that could support his envisioned development of Nauvoo. Thus, he accepted Galland's offer and appointed church agents to hold title to the Iowa lands. ${ }^{4}$ Seven years later, in 1846, when the

11. For an account of the Mormons' various experiences in Iowa, see Hartley, "Mormons and early Iowa History."

12. Lyndon W. Cook, "Isaac Galland-Mormon Benefactor," Brigham Young University Studies 19 (1979), 267. See also Robert Bruce Flanders, Nauvoo: Kingdom on the Mississippi (Urbana and Chicago, 1965), 25-37. This Fort Des Moines should not be confused with the better-known fort of the same name established upriver in 1843 near the site of the future state capital.

13. Record of Deeds, Book 2, Des Moines County Recorder's Office; Indexes to Deeds (both grantor and grantee), numerous entries under "G," Lee County Recorder's Office.

14. Joseph Smith Jr., History of the Church of Jesus Christ of Latter-day Saints, ed. B. H. Roberts, 7 vols., rev. ed. (Salt Lake City, 1980), 3:260, notes that at a church conference held in Quincy, Illinois, Galland's proposal was presented 
Mormons were exiled from the Nauvoo region, they also left vacant the lands they had purchased from Galland on both sides of the Mississippi. It would be another seven years before the Saints would return to Keokuk and temporarily inhabit the area again.

THE INSECURITY of land titles in the Half Breed Tract, which included the town plat of Keokuk, had kept migration to the southeastern corner of Iowa at a minimum during the 1840s. In 1852, however, several New York businessmen, in a series of court struggles, won undisputed claim to 40 percent of the Half Breed Tract. ${ }^{15}$

With secure land titles in the region, Keokuk began to boom. From an 1850 population of 2,117, the town grew to 3,256 by October 1852. ${ }^{16}$ It had been surveyed for a grid of streets one mile square, but numerous ravines made travel on the streets problematic. Atop the bluff, retail and craft-trade establishments lined Main Street. A particularly deep ravine bisected Main Street where Sixth Street was supposed to cross. On the riverfront, wholesalers' warehouses stored goods offloaded from the river traffic. These goods included all the necessities that settlers could not grow or make. The city council had two primary con-

for approval as "a liberal offer [which] had been made by a gentleman, of about twenty thousand acres, lying between the Mississippi and Des Moines river, at two dollars per acre, to be paid in twenty annual installments, without interest." Galland was at that time viewed as a Mormon benefactor. According to Flanders, Kingdom on the Mississippi, 132-34, in July 1839 Galland converted to Mormonism and agreed to act as a secretary to President Joseph Smith. In 1841 he wrote a defense of Mormonism, but by 1842 his relationship with the church had soured, and he withdrew his fellowship. Flanders also notes (3637) that apparently Vinson Knight and Oliver Granger represented the Mormons as trustees for the bulk of the Iowa lands acquired. The 1840 census reveals nearly 1,000 Mormon residents in the Half Breed Tract, among them future church presidents Brigham Young and Wilford Woodruff. See Helen Blumhagen et al., "The 1840 Iowa Census and Index" (1968), 142-79, Keokuk Public Library.

15. The Mason-Remy Collection of Correspondence, State Historical Society of Iowa, Des Moines, contains numerous letters dealing with this issue. The New Yorkers accepted Charles Mason's proposal that he buy the entirety of their interests in the tract, effective 30 June 1852.

16. J. W. Delaplaine, "Alphabetized Transcript of Special Census," manuscript copy, 1901, 131, Keokuk Public Library. 


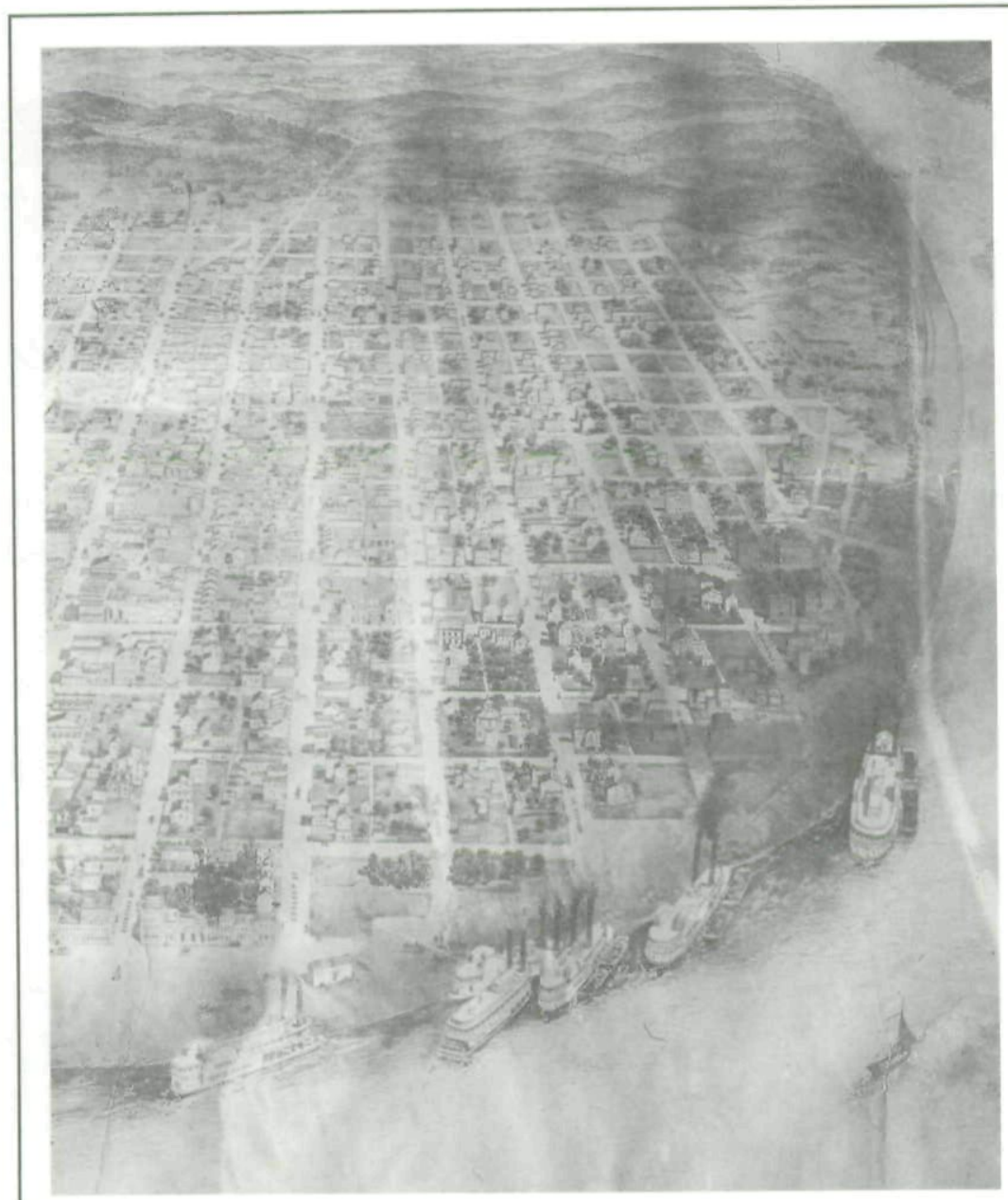

This lithograph by J. T. Palmatory renders the artist's vision of Keokuk in 1857. The 1853 Mormon encampment would have been located on the bluffs along the river just north of the developed portion of the city. Courtesy of Lee County Historical Society.

cerns: setting street grades to facilitate the population's movement to and from the "downtown," and regulating use of the wharf as a source of taxes to finance the necessary street work. ${ }^{17}$

17. Isaac Galland and Henry Austin claimed credit for the civic plan. Proceedings of the City Council were regularly reported in the Valley Whig and/or 
With foundry workers, wagon makers, hardware wholesalers, pork packers, carpenters, and stone cutters all busy, the town could absorb immigrant laborers. Numerous Irish and German immigrants arrived, and values for platted lots rose dramatically.

In that context, Mormon church leaders decided to outfit LDS European immigrants and North American emigrants at Keokuk for the 1853 migration season. At Keokuk the emigrants would earn funds by laboring where possible, await equipage for the cross-country trek, and get some training in the challenges of survival on the prairie.

DURING THE SPRING AND SUMMER of 1853, more than 2,500 Mormon emigrants would swell the population of Keokuk, which was estimated at about 3,000 before their arrival. One historian noted, "By 1853, Keokuk had more people than its houses could shelter, although the citizens were building houses at a rapid rate."18 The Keokuk Dispatch reported, "The suburbs were occupied by tents ranged in close order, over a mile square in extent, and sheltering upwards of 2,000 persons. ${ }^{\prime 19}$

The influx of Mormon emigrants would produce even more temporary shelters. Mormon agents had selected an area on the northeastern edge of Keokuk for their encampment. Keokuk historian Alois J. Weber explained, "The authorities and people of Keokuk co-operated with the Mormons and rendered them every assistance and at Sugar Creek a field of 2000 acres was offered to the emigrants for pasture for their livestock."20 The

Keokuk Dispatch, although not all dates survived to be microfilmed. See also Ivins, "Yesterday: Reminiscences of Long Ago," 28; Davis Scrapbooks (10 vols.), 1:7, Keokuk Public Library.

18. Faye Erma Harris, "A Frontier Community: The Economic, Social, and Political Development of Keokuk, Iowa from 1820 to 1866 " (Ph.D. diss., University of Iowa, 1965), 179.

19. Keokuk Dispatch, 5 May 1853.

20. Weber, "History of Mormon Encampment at Keokuk in 1853," 4. The Sugar Creek cattle encampment was near Montrose. It is not the Sugar Creek Camp (about nine miles west of Montrose) used by the Mormons who left Nauvoo in 1846 , but rather one that was very close to the Keokuk encampment. Hannah Tapfield King seems to indicate in her journal entry for May 27, 1853, that the pasture at Sugar Creek was within a short walking distance of the camp. See "My Journal: Hannah Tapfield King," in Kenneth L. Holmes, ed., Covered Wagon Women (Glendale, CA, 1986), 191. 
encampment on that field on the outskirts of Keokuk served as a temporary gathering place for European converts, largely from Great Britain, with several hundred from Scandinavia, who were preparing to cross the plains to the Salt Lake Valley.

Such preparations had begun far in advance. The foreign converts received annual direction from church leaders. At the close of the 1852 migration season, the First Presidency sent an epistle encouraging the Saints to gather the ensuing year "as doves fly to their windows before a storm." There was also regular correspondence between church leaders and agents in Europe as well as in America. From church headquarters in Salt Lake City President Brigham Young kept a careful watch over all aspects of Mormon migration. He also delegated responsibilities to emigration agents, who regularly informed him of emigration matters from where they were positioned along the road to Zion. Expressing his confidence in his emigration agents in 1853 , he wrote, "Our agents, are in various parts of the United States and Europe, assisting by all the means in their power, the progress of this work." ${ }^{\prime 1}$

During the 1853 emigration season, agents were stationed in several locations. ${ }^{22}$ Willard Snow presided over the Scandinavian Mission and was thus responsible for overseeing emigration from Copenhagen. ${ }^{23}$ Samuel W. Richards was the president of the British Mission and launched the emigrants from Liver-

21. Brigham Young to "Brethren" (male church members) in Iron County, Utah Territory, 18 June 1853, Brigham Young Collection, LDS Church Archives. See also, for example, the following letters from Mormon emigration agents during this period in the Brigham Young Collection, LDS Church Archives: Horace S. Eldredge to Brigham Young, 21 April 1853; Samuel W. Richards to Brigham Young, 22 April 1853; Isaac C. Haight to Brigham Young, 1 July 1853.

22. The agents kept in contact with each other. See Samuel W. Richards to Brigham Young, 22 July 1853, Brigham Young Collection, LDS Church Archives, in which Richards informs Young of an emigration balance sheet he had regarding the account of Isaac C. Haight, who was the Mormon emigration agent in Keokuk in 1853.

23. Andrew Jenson, History of the Scandinavian Mission (Salt Lake City, 1927), 54, points out that Snow "took full charge of the mission when Elder John E. Forsgren, with a company of emigrants, left for Utah in December, 1852." Forsgren's company of nearly 300 Scandinavian converts crossed the Atlantic on the Forest Monarch before arriving in Keokuk. 
pool. ${ }^{24}$ The designated port of entry for 1853 was New Orleans, where agent John Brown met incoming vessels filled with Mormon companies. ${ }^{25}$ The emigrants proceeded up the Mississippi more than a thousand miles to St. Louis, where Horace S. Eldredge, the local Mormon emigration agent, met them. ${ }^{26}$

By January 1853, Eldredge was corresponding with both Richards and Brown. On February 8, 1853, he noted Isaac Haight's arrival from Liverpool. Haight and Eldredge then began to prepare for the emigration season, purchasing 14 wagons for $\$ 58.00$ apiece from Louis Espenschied in St. Louis. ${ }^{27}$

While Eldredge spent the bulk of his time supervising migration in St. Louis, Haight headed upriver to play a prominent role in migration matters at Keokuk. Haight not only selected

24. Between January 6 and April 6, 1853, 2,586 Latter-day Saints left Liverpool on eight voyages. Seven of these voyages were made up of British converts and one of Danish proselytes. The Danish group led by John E. Forsgren was the first large LDS Scandinavian company to immigrate to America. These LDS voyages arrived in New Orleans sometime between March 6 and June 7, 1853. These foreign converts then made their way up the Mississippi via St. Louis to Keokuk by steamboats. See Deseret News 1997-98 Church Almanac (Salt Lake City, 1996), 161.

25. David Buice, "When the Saints Came Marching In: The Mormon Experience in Antebellum New Orleans, 1840-1855," Louisiana History 23 (1982), 22137 , provides a nice overview for this period during which more than 18,000 Latter-day Saints migrated through the port of New Orleans. Buice notes (232) that John Brown, from Tennessee, served as the Mormon emigration agent at New Orleans from 1852 through 1854.

26. Stanley B. Kimball, "The Saints and St. Louis, 1831-1857: An Oasis of Tolerance and Security," Brigham Young University Studies 13 (1973), 510, indicates that in October 1852, Eldridge [Eldredge] was appointed from Utah to oversee the St. Louis church district and to serve as the general emigration agent for the Latter-day Saints in St. Louis. However, this call was probably extended earlier; Eldredge noted in his journal that he left Salt Lake City for St. Louis on September 15, 1852, and began making purchases for emigrants in February 1853. Horace S. Eldredge, Journal, September 1852-April 1854, LDS Archives. Kimball further notes that during the 1853-54 emigration seasons, Eldredge was responsible for purchasing about 4,000 head of cattle and 800 wagons.

27. Eldredge Journal, 24, 26, and 31 January and 8 February 1853, LDS Church Archives. See also ibid., 12, 22 and 23 February 1853. Louis Espenschied was a German who immigrated to St. Louis in 1840 at age 19 . His wagons were regularly advertised in the Latter-day Saint newspaper, the St. Louis Luminary. For more information on his life, see the article by his grandson, also named Louis Espenschied, "Louis Espenschied and His Family," Missouri Historical Bulletin 18 (1962), 86-103. 


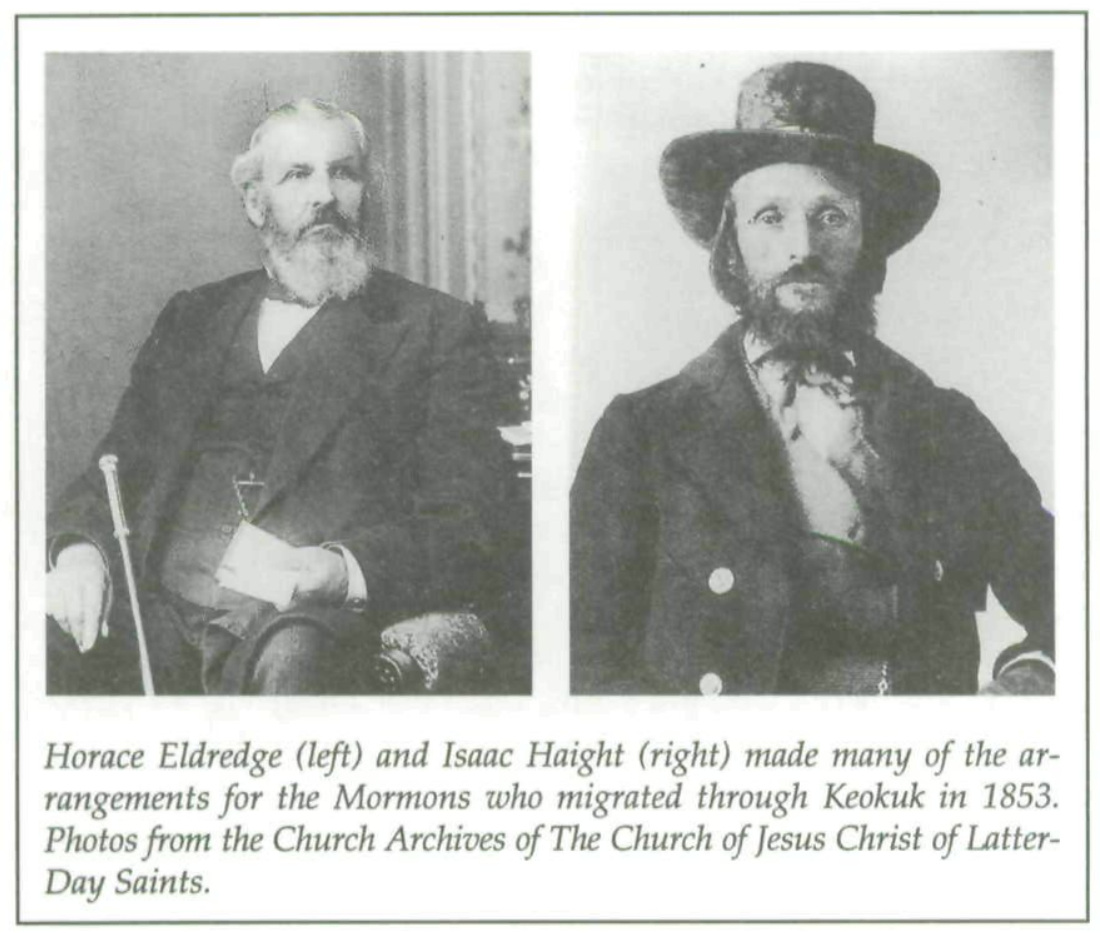

the site for the 1853 Mormon encampment, but he was also involved in local business transactions to prepare for the incoming emigrants. Haight made the following notes in his journal in the early spring of $1853:^{28}$

March 24 Thurs. Started with 50 wagons up the Mississippi River. ${ }^{29}$ March 25 Fri. Arrived at Keokuk, looked out for a location on the bluff north of the town.

March 26 Sat. Bot [Bought] 8 yoke of cattle at Alexandria.

March 28 Mon. Went out in the country to find a place to keep our cattle. Mr. Potter kindly offered to let me keep them on his land back of Montrose, the principal men of Keokuk were please to have me fit out the Emigrants at that place. In the evening started for St. Louis.

28. Isaac C. Haight, Journal, 24 March-5 April 1853, Special Collections and Archives, University Libraries Special Collections, Utah State University, Logan.

29. Eldredge Journal, 23 March 1853, LDS Church Archives, notes, "In the evening Br.s [Brothers] Haight \& Shurtliff left on board the Hindoo for Keokuck. ... I attended in the office with the Saints that are a going to emigration." 
March 30 Wed. At St. Louis found a company of Saints, got them aboard the steamer Hindoo for Keokuk. ${ }^{30}$

March 31 Thurs. Made a contract with Mr. Ames for bacon. ... .

April 5 Tues. Contracted with Isaac Henry of Ill. To purchase me 280 cows at $\$ 21.50$ per head. Started for Keokuk.

April 7 Thurs. Arrived had a meeting with the Saints, gave them much instruction, had much of the spirit my heart rejoiced in the Lord to see his Saints gather home.

While Haight oversaw the migration in Keokuk, Eldredge made arrangements for Mormon emigrants to leave St. Louis and proceed upriver by steamboat to Keokuk. ${ }^{31}$ On March 31, 1853, Eldredge noted, "We made a contract with the Keokuck Packet Co to take up our emigration and freight to that point [Keokuk] at the following rates, for [probably meaning four] cabin passengers $\$ 3.50$, adult cabin passengers $\$ 1.00$ [probably meaning for each one], Children 2 year old to 14,50 [cents] \&c. ${ }^{\prime \prime 2}$ Thus, during the 1853 emigration season, most Mormon immigrants traveled up the Mississippi from St. Louis to Keokuk on steamboats owned by the Keokuk Packet line. The distance from St. Louis to Keokuk was about 200 miles, and the trip usually took only 24 hours..$^{33}$

30. Ibid., 30 March 1853, notes that a group of British Saints had arrived in St. Louis the previous night and a portion of them had been immediately reshipped on the steamboat Hindoo to Keokuk.

31. Haight was also involved in arranging for passage up the Mississippi. He recorded in his journal on 19 April 1853, "Got the Saints that came on the Ellen Maria on the Packet for Keokuk." It appears that he had come to St. Louis for provisions. Haight noted in his journal on 20 April 1853, "Made contract for shipping our provisions to Council Bluffs started for Keokuk in the evening."

32. Eldredge Journal, LDS Church Archives, 31 March 1853. According to journal entries for 30 and 31 March 1853, the "we" who were involved in this business transaction appear to be Eldredge, as well as Isaac Haight and Vincent Shurtliff, who had just returned from Keokuk. Orson Pratt, who had just arrived from Washington, and Cyrus Wheelock also appear to have taken part in this emigration deal.

33. Keokuk Dispatch, 22 February 1853, states that the total distance from New Orleans to Keokuk is 1,251 miles and from St. Louis to Keokuk, 205 miles, and adds, "The Keokuk packet line for the coming season, we are informed will consist of three first class steamers-the Jeanie Deans, Die Vernon, and Kate Kearney." Migrating Saints used each of these steamboats and several others (including the Hindoo) during the 1853 emigration season. 
On April 21, 1853, Eldredge reported to Brigham Young regarding his absorption in migration matters on the Mississippi. "We are getting along well with the Emigration from the Old Country there has been five ship loads Passed up to Keokuk \& three more expected averaging 300 to 425 besides a great many coming from the east. It is a very busy time with us here at Present \& I am in great Haste for there are several waiting on me at this time to attend to Business. ${ }^{134}$

DISEMBARKING AT KEOKUK, the Mormon emigrants spent their first night near the wharf beneath various kinds of shelter. One emigrant wrote, upon reaching Keokuk, "Had to stay in the depot all night." Peter McIntyre slept in "a large stone house." Another emigrant reported, "Arrived at Keokuk about 7 p.m., got our things landed in the shed about 11 o'clock. Stopped in the shed through the night." Three women recalled their temporary overnight quarters in a warehouse. Hannah Cornaby, for example, described staying "in a large warehouse on the levee without any accommodation but that afforded by luggage.",25

Latter-day Saints who had arrived earlier willingly volunteered to help the incoming emigrants reach the Mormon encampment from the Keokuk levee. The volunteers were probably not officially assigned to aid in migration matters. One emigrant recalled, "Brother Locke and others brought their teams and [helped] the Saints to bring their luggage to the camp of Israel. 34. Horace S. Eldredge to Brigham Young, 21 April 1853, Brigham Young Col-
lection, LDS Church Archives.

35. Robert Warner Jr., Journal, in Chronicles of Courage, 8 vols. (Salt Lake City, 1992), 3:182 (see also Cornelius Bagnall Emigrating Company, 28 May 1853, LDS Church Archives, which states, "We arrived at Keokuk and stopped in the depot all night"); Peter McIntyre, Autobiography, 28 May 1853, LDS Church Archives; Hannah Cornaby, Autobiography and Poems (Salt Lake City, 1881), 31; Joseph W. Young Emigrating Company, Journal, 12 April 1853, LDS Church Archives; Elizabeth Fovargue Smith, Journal, 9, copy in possession of Fred E. Woods; Christian Nielsen Munk, Journal, 21 April 1853, LDS Church Archives. The warehouse may have been owned by John S. McCune, who was at that time the principal owner of the St. Louis and Keokuk Packet Line and who also owned a warehouse on the wharf at Keokuk. As early as January 1852, McCune owned three adjoining lots at the Keokuk levee. See Lee County Register of Deeds, Book 12, 337, 493, Lee County Courthouse, Keokuk. 
A sight which gladdened my heart to behold. ${ }^{136}$ Upon reaching the encampment on the outskirts of Keokuk, the Saints were placed under the competent charge of the local Mormon agent, Isaac C. Haight, and his assistant, Vincent Shurtliff, who had made the necessary arrangements for the incoming migrants. ${ }^{37}$

Most of the emigrants were generally pleased with what they found at the encampment. As one migrant noted, "Elder Isaac C. Haight, who was the Church Emigration agent at the outfitting point, selected a very healthy camping place at Keokuk, on a bluff near the river, where there was plenty of wood and grass handy. The citizens of Keokuk manifested a benevolent feeling towards the Saints, which was highly appreciated by them." Stephen Fosdick recalled, "The Mormon Camp consisted of a long street with wagons on each side. We were shown our camp, which consisted of about twenty empty wagons, equipped with bows. ... . we were told to divide ourselves into groups of ten, and each ten to take possession of a wagon." Another migrant, Christopher Jones Arthur, remembered, "The camp was lively, scattered over many acres. Some in tents others in wagons." Scandinavian convert Christian Nielsen described the encampment as "open air quarters." He noted, "In the morning I went out to see our 'open air' lodging place that looked well to me. We came first to the place where emigrants from England were placed, and thereafter to the spot where we Danish emigrants should have our quarters.... We could help ourselves to all the wood we needed." Less than a week later, Nielsen noted, "Our 'territory' for quarters gets wider day after day. Each day additional wagons loaded with emigrants come to our quarters, and tents are put up to be the abode for the emigrants. ${ }^{138}$

36. John Paternoster Squires, Reminiscences and Journals, 8 May 1853, LDS Church Archives.

37. Edward Kingsford, Autobiography, LDS Church Archives, 1; Jacob Gates, Journals, LDS Church Archives, 5:133 (note: the journal pages are not numbered; this is the authors' own pagination, and this entry is on the last page of volume five).

38. Church Emigration Book 1853, LDS Church Library, Salt Lake City; Stephen Fosdick Jr., ed., "On the Oregon Trail to Zion in 1853: Memoirs of Stephen Fosdick," in The Denver Brand Book, 10 vols. (Boulder, CO, 1953), 9:36; Christopher Jones Arthur, Autobiography, 6, LDS Church Archives; Christian Nielsen, Diary, 1, 2, and 8 May 1853, LDS Church Archives. 


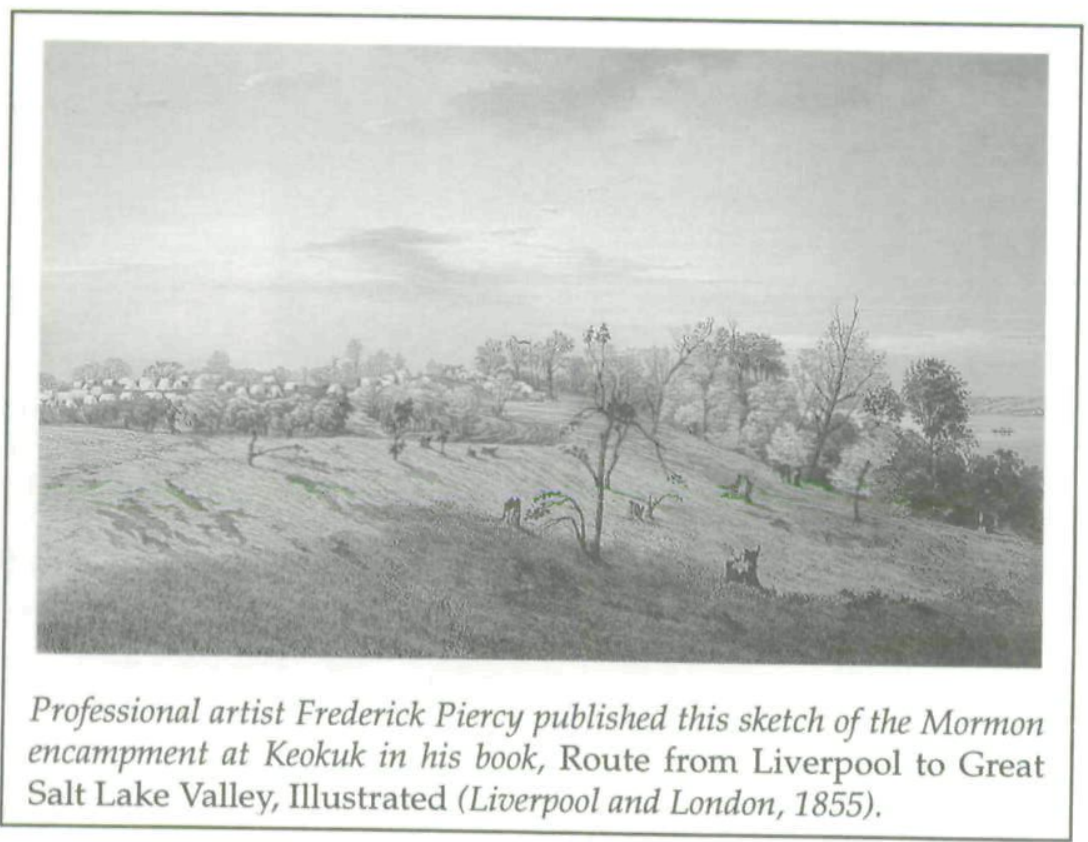

Frederick Piercy provided a vivid description of the Mormon encampment through the eyes of a gifted British artist:

I sallied out in search of the Camp, which, after climbing a steep bluff on the edge of the river, I found most picturesquely situated on top of a hill, surrounded by wood, and commanding a view of the country for miles around. The situation was admirably chosen, as there were good drainage and an abundance of wood and water combined. It was just daylight, and the guards had retired to their tents. Upon my entrance all was still in the Camp, no person was to be seen.

Piercy also described the social condition that was the result of a mixture of European converts:

The emigrants from each nation had wisely been placed together, and those who had crossed the sea together were still associated as neighbours in Camp. I heard no complaints of sickness, and I was told that the general health was good. The Elders in charge seemed thoroughly competent, and Elders Haight and Eldredge were incessant in their labours. I particularly noticed the generosity with which Elder C. H. Wheelock volunteered the use of his teams for the public good. They were constantly engaged in 
transporting the luggage of the emigrants from the river to the Camp, which saved many a poor person's scanty means, and rescued many a poor family from a dilemma, for as yet there were a very few oxen in the Camp, and most persons were unwilling to run the risk of their animals being worn out before the commencement of the journey.

The Camp was in excellent order, and the emigrants informed me that when the ground was not muddy they would as soon live in a tent as in a house. I saw few idlers-indeed, rather than remain unemployed until the trains moved off, those who could not get work in the town of Keokuk at their trades took advantage of the opportunity which [was] offered of working on the roads. By this means they saved what little money they possessed, and in many instances added to their stock, and were thus enabled to obtain many little comforts which they must otherwise have gone without. . . . Before leaving Keokuk I made the accompanying sketch of the Camp, showing the arrangement of the wagons and tents, which, with their white covers, looked extremely picturesque amidst the spring foliage of the country. ${ }^{39}$

There was joy in the Mormon camp when the European Saints reunited with acquaintances from their homelands on American soil. James McNaughton registered "the unspeakable pleasure of being in the camp of Brothers Barnes \& Allen, from Hull and of seeing their families. What a meeting!" McNaughton also noted that the Saints met weekly for public worship at the camp. Such meetings, he commented, were "good times" when "the Lord truly blessed us." ${ }^{\prime 0}$

During the several weeks during which Latter-day Saints prepared for their overland journey, some had a little time to explore the surrounding area. Some took time to see the dilapidated Nauvoo Temple and to visit Emma and Lucy Mack Smith, the widow and mother of the martyred Prophet Joseph Smith. ${ }^{41} \mathrm{Al}-$

39. Frederick Piercy, Route from Liverpool to Great Salt Lake, 59-60. On Piercy's life, see Wilford Hill Lecheminant, "Entitled to Be Called an Artist: Landscape and Portrait Painter Frederick Piercy," Utah Historical Quarterly 48 (1980), 49-65.

40. James McNaughton, Journal, 29 May and 5 and 12 June 1853, LDS Church Archives.

41. See ibid.; [Autobiography] of Sarah Birch Waters, Our Pioneer Heritage, 11:164; Jane Ann Fowler Sparks, Reminiscences and Diary, 14, LDS Church Archives; and Hannah Tapfield King, Autobiography, 1 May 1853, ibid. 
though most were very busy with their preparations, they enjoyed socializing with one another.

Sometimes, though, frontier conditions created hardships for the emigrants. Upon arrival at Keokuk, Hannah Cornaby described the Mormon encampment on a hill near the Mississippi River.

Here we found the wagons and tents. We had just placed our baggage in the wagons; some were making awkward attempts at erecting tents while others were trying to place the covers on the wagons, some of which obstinately refused to reach over at both ends, when we were struck by a furious storm of wind and rain, accompanied by thunder and lightning such as we had never heard or seen before. The storm raged with such fury that we feared the wagons would be upset, and after the wind subsided, the rain poured down incessantly three days and nights, our luggage and bedding becoming thoroughly soaked, and the camp ground ankle deep with mud. Under these circumstances, my second child was prematurely born. ${ }^{42}$

Not all of the descriptions of Mormon emigrants came from the emigrants themselves. The Keokuk Dispatch carried articles relating to the arrival of the Mormon emigrants. In April 1853 the paper reported,

Two hundred Mormons arrived here on Friday last on board the steamboat Hindoo on their way to Salt Lake, several hundred more are lying at St. Louis and two or three ship loads expectedly daily from New Orleans. Those who have arrived have gone into camp above the city incorporation. They are all native of England and Wales and left the port of Liverpool on the 18th of February last for New Orleans, where they arrived safely and in good health, having lost but one of their number on the way. The whole train when it is made up, it is expected will number two thousand persons. They intend making Keokuk their starting point. Farmers having stock or cattle fit for the yoke will here find a ready market.

Just one week later, the Dispatch added, "Two hundred more of the Mormon faith arrived at this place on last Sunday. They have also gone into camp awaiting the arrival of about two thousand more who are expected here soon." By the end of May, the paper

42. Cornaby, Autobiography and Poems, 31. 
reported, "During the past [week] some eight hundreds [sic] Mormons have left and some three hundred have arrived at the camp ground. About 3000 have already reached this port and about 800 more are expected. The Mormons have behaved in the most peaceable and courteous manner during their stay here and have won the respect and confidence of the community with their orderly and law abiding behaviour."

Saints earned some of that respect through physical labor they performed for the betterment of Keokuk. The Dispatch reported on April 26,

A large number of Mormons are now employed in grading the streets of our city. Each man is a "full team" behind a pick and shovel. A pile of dirt before a dozen or two of these hard fisted, strong fellows, is "nowhere." The rough places of our city are rapidly becoming smooth and if the Mormons remain here awhile longer, our streets will present quite a different appearance from what they have presented heretofore. We are not sorry to see this improvement going on. Nothing needs improvement worse than the streets of our city. ${ }^{4}$

Some of the Latter-day Saints did indeed find employment grading the streets, and apparently some of the men secured temporary work in town at their trades. Some of the women apparently also found work cleaning the homes of the locals in Keokuk. For example, William Belknap noted in a letter to his sister that he and a local resident named Mrs. Van Antwerp were going "up to the [Mormon] camp this afternoon as she wants to find some women to clean her house." ${ }^{\prime 45}$

Some emigrants were creative in capitalizing on their journey. One British convert observed, "Many of the brethren obtained employment. Our Scandinavian brethren, with characteristic industry and forethought, purchased trees from the owners of the neighboring forests, from which they manufactured a variety of useful articles. . . . All were busy preparing for the journey."

43. Keokuk Dispatch, 5 and 12 April and 31 May 1853. See also ibid., 7 June 1853.

44. Ibid., 26 April 1853.

45. William W. Belknap to his sister, Clara, 9 May 1853, microfilm, Keokuk Public Library.

46. Cornaby, Autobiography and Poems, 31-32. 
Another group of emigrants, including company leader Christopher Jones Arthur, John Lyon, and poet Henry Maiben, joined funds to print hundreds of copies of their inspiring ocean narrative after they survived a terrifying storm with more than four hundred converts aboard the International. Among other things, their eight-page document told the story of how the captain of the International (David Brown) had dreamed that he and his crew would be converted to Mormonism. Before reaching New Orleans, Captain Brown, two of his mates, and 18 crew members had all yielded to the ordinance of baptism. ${ }^{47}$

Although the Latter-day Saints must have worked hard to convert the "salty" mariners on board the International, the task of obtaining expensive teams, wagons, cattle, and oxen required even more patience and effort for those who had never yoked oxen or worked with cattle. Isaac Haight and Vincent Shurtliff purchased the teams and wagons in St. Louis and elsewhere. The wagons and beasts of burden purchased at St. Louis were loaded onto steamboats and sent upriver to Keokuk. ${ }^{48}$

47. This eight-page document, apparently written by John Lyon, "Diary of a Voyage from Liverpool to New Orleans on Board the International ..." (Keokuk, 1853), is located in LDS Church Archives. The Christopher Arthur Emigration Company Journal, 20-23 May 1853, LDS Church Archives, reveals that Elders Arthur, Jones, and Maiben joined funds to print copies of the story. John Lyon's personal diary, LDS Church Archives, 13-16, notes that Henry Maiben wrote a song about this unique voyage to commemorate the anniversary of the church held on board 6 April 1853. Lyon also recorded the ten verses of lyrics. For an overview of this unique voyage and the accompanying lyrics, see Fred E. Woods, "On Board the 'International,' All Joyful and Lighthearted," The Log of Mystic Seaport 51 (Summer 1999), 23-25. Although all of the crew were baptized, perhaps not all were converted. In a letter written just one year after the voyage of the International, Thomas Fisher, writing to the editor of the Liverpool-based Latter-day Saints Millennial Star 16 (15 July 1854), 448, noted, "Two of the crew-the carpenter and a sailor, are going with us to Zion. They have been engaged as teamsters by some of the passengers, and will be baptized after leaving the ship. It is prudent not to baptize seamen on board-it has proved that they sometimes get baptized on board merely to assist in their designs upon the honors of our sisters. We might have baptized all our crew, mates and all, but President was too old for them."

48. Edward Kingsford, Autobiography, LDS Church Archives; Journal History of The Church of Jesus Christ of Latter-day Saints, The Church of Jesus Christ of Latter-day Saints, Library Division, Salt Lake City [which contains miscellaneous information from newspaper clippings, journals, autobiographies, biographies, etc. about the LDS Church from 1830 to the present], 20 May 1853; James Harwood, Autobiography, LDS Church Archives, 3. 
Some of the Latter-day Saint emigrants assisted Haight and Shurtliff by obtaining the needed cattle and oxen in places other than St. Louis. One Mormon emigrant noted, "I was one out of 13 that was called upon to go into Bonvil [Boonville] 5 hundred miles in the state of Missouri to by [buy] up 8 hundred head of oxen to take that seasons emigration across the plains. ${ }^{149}$

Sometimes difficulties securing the necessary teams forced emigrants to modify their plans. One emigrant recalled that when his wagon was just about ready to pull out of Keokuk, he was told, "You have been selected to remain here in company with three others to bring a herd of cows when they come." The frustrated teamster commented, "I had never been one day away from my wife before since we were married." Another emigrant noted that when he left Liverpool, he understood that upon reaching Keokuk his company would have ten people to a wagon and they would be allowed one hundred pounds of luggage. Yet when he arrived, "we had to take twelve in a wagon and consented to reduce our extra luggage to seventy-five pounds and if possible to fifty. There was no way to hire out extra luggage taken to the valley so we burned our boxes and extra weight." Such were the expectations for those who chose to journey with the Latter-day Saints..$^{50}$

The Scandinavian immigrants departing Keokuk had an especially difficult time yoking the oxen. "Some of the Scandinavians, disliking the American way of driving oxen in yokes, hitched up these beasts of burden in regular Danish fashion. But they had forgotten one little thing - that the oxen were American. ... It was decided that it would be easier for the emigrants to learn American ways than it would be for the oxen to learn to work with the Danish harness." ${ }^{\prime 51}$

The British immigrants also had a difficult time with the animals. Hannah Cornaby vividly recalled, "The oxen were wild, and getting them yoked was the most laughable sight I had ever

49. John Isaac Hart, Autobiography and Journal, 78, LDS Church Archives.

50. Joseph Greaves to his cousin, William Greaves, 14 September 1897, LDS Church Archives; The [Autobiography] of James Ririe, in Our Pioneer Heritage, comp. Kate B. Carter, 20 vols. (Salt Lake City, 1958-1977), 9:355.

51. Albert L. Zobell, Under the Midnight Sun: Centennial History of Scandinavian Missions (Salt Lake City, 1950), 48-49. 
witnessed; everybody giving orders, and nobody knowing how to carry them out. If the men had not been saints, there would doubtless have been much profane language used; but the oxen, not understanding 'English,' did just as well without it." ${ }^{52}$

Most foreign converts had a trying time once they began their westward trek from Keokuk. One emigrant stated, "The Saints generally thought the way to Zion was a hard road to travel but found out later that they were not up against the real thing until they began to outfit for the plains and come in contact with a herd of wild Texas cattle with horns like a rainbow."153

James Pett explained, with a little humor, the difficult and frustrating experience for some who were inexperienced with an overland journey. He wrote of "one little incident that occurred on the road" during his 1853 journey.

One of the crew of the old ship Elvira Owen (the carpenter) fell in love with one of our Mormon sisters and came up with the company to St. Louis and stayed over there a few days and got married and then came to Keokuk with the intention of crossing the plains with some of the companies and brought their wagon, ox team and outfit complete and started out on the fearful muddy road and Smith (that was his name) was not accustomed to such traveling and driving oxen through mud half leg deep, so after traveling a few miles, he began to despair as he found out that land traveling was far more unpleasant than it was to walk the decks of an ocean schooner under like conditions, and he became very abusive as nothing suited him, and finally he threw down his ox whip and declared that he would not go another step farther. So after a little parleying with his wife, he took his bundle of clothes and went back to the sea, and his wife hired a young man to drive the team and she came to the Valley, and that was the last of Smith. ${ }^{54}$

Given the difficulties and the emigrants' lack of experience, company leader Moses Clawson was especially grateful to make it to Fort Laramie with the "Company all well, and teams in good condition" even though nearly all the teamsters in his

52. Cornaby, Autobiography and Poems, 2.

53. John Fell Squires, Autobiographical Sketch, 3, LDS Church Archives.

54. James Pett, Autobiography, in B. Glen Marble, Mormon Marbles: Roots and Branches (privately printed, 1979), Church Historical Library, 68-71. 
company were ignorant of working with cattle. Nine other companies of Mormon emigrants left Keokuk within a month of Clawson's company's departure. All of these companies, totaling 2,548 emigrants with 360 wagons, reached the Salt Lake Valley safely during the fall of $1853 .{ }^{55}$

THE COST of the cattle and oxen and the time to gather them across the state of Missouri, coupled with the fact that crossing Iowa added about 300 miles of land travel, shows why Keokuk was chosen as the Latter-day Saint outfitting point for 1853 only. Furthermore, in a letter dated July 23, 1853 (after all companies had left Keokuk), emigration agent Horace Eldredge informed Brigham Young, "There is a verry good Class of Boats running the Missouri River." He recommended that Fort Leavenworth, Kansas, be used as an outfitting post if church officials decided to take emigrants up the Missouri next season. "I think from what I can learn thus far that Lexington Mo will be the best place for us to get cattle at. ${ }^{156}$

Church officials did follow Eldredge's counsel, and the following year emigration agent William Empey designated the area of Kansas City, Missouri (just 13 miles northwest of Independence) as the outfitting post, with Westport as the appointed landing place..$^{57}$ Although the Saints ran the risk of plying the "big muddy" and although some no doubt had memories of the Saints being driven from that part of Missouri, the plan saved them hundreds of miles of travel across Iowa. Furthermore, if the cattle were to be purchased in the vicinity of Lexington, Missouri, that would also save hundreds of miles of travel to the

55. Moses Clawson to Brigham Young, 7 August 1853, Brigham Young Collection, LDS Church Archives; "Pioneer Companies That Crossed the Plains," 1997-98 Church Almanac (Salt Lake City, 1996), 170-71. Hartley, "Mormons and Early Iowa History," 251, notes that "these 1853 LDS wagon trains made the Iowa crossing in an average of four weeks [compared to the three-and-a-half months it took for the better-known Mormon Trek across Iowa following the Spring Exodus in 1846] even though, as James Ririe recalled, 'across Iowa the roads were bad and we greenhorns poor teamsters' " ("James Ririe-Archibald McFarland," Our Pioneer Heritage 9 [1955], 335).

56. Horace S. Eldredge to Brigham Young, 23 July 1853, Brigham Young Collection, LDS Church Archives.

57. Piercy, Route from Liverpool to Great Salt Lake Valley, 60. 
farther city of Keokuk, and the wagons they purchased in St. Louis could be transported by steamboats to the outfitting post.

Although Keokuk was designated as the outfitting post for only one year, the temporary presence of the Mormon emigrants left an imprint. Not only did Keokuk benefit economically from purchases the Mormons made there for the journey across the plains, but the Latter-day Saints also contributed to a substantial improvement of Keokuk's city streets. In an article titled "The Mormons at Work," the Keokuk Dispatch reported, "The rough places of our city are rapidly becoming smooth, and if the Mormons appear here awhile longer, our streets will present quite a different appearance from what they have presented heretofore." In fact, the paper claimed, with the help of the Mormon graders, Keokuk's Main Street already had become "one of the handsomest streets in this or any other country."

But the Mormons' presence left a moral as well as physical imprint. Keokuk resident William W. Belknap observed that the Latter-day Saint emigrants were "devoted to their creed \& enthusiastic in faith they are models in conduct for men of more christianized churches. Public prayer every morning and evening. ... Such a sound of an oath is never heard. ${ }^{159}$

Although their presence was temporary, the more than 2,500 Latter-day Saints who migrated through Keokuk in 1853 left a positive lasting impression on the city and citizens of Keokuk.

58. Keokuk Dispatch, 17 May 1853.

59. William W. Belknap to his sister, Clara, 3 May 1853, in Weber, "History of Mormon Encampment at Keokuk in 1853," 9-10. As noted previously, a microfilm copy of the Belknap correspondence is housed at the Keokuk Public Library. However, this particular letter is missing from the microfilm and was apparently part of the original collection used by Weber, which was later given to Princeton University. 
Copyright of Annals of Iowa is the property of State of Iowa, by \& through the State Historical Society of Iowa and its content may not be copied or emailed to multiple sites or posted to a listserv without the copyright holder's express written permission. However, users may print, download, or email articles for individual use. 